\title{
Calorie conversion factors. An experimental reassessment of the factors used in the calculation of the energy value of human diets
}

\author{
By D. A. T. SOUTHGATE \\ Dunn Nutritional Laboratory, University of Cambridge \\ and Medical Research Council, Cambridge \\ AND J. V. G. A. DURNIN \\ Institute of Physiology, The University, Glasgow \\ (Received I7 September 1969-Accepted Iо December 1969)
}

\begin{abstract}
I. The intake and excretion of total nitrogen, fat and the various forms of carbohydrate, and the heats of combustion of the diet, urine and faeces were measured in groups of young men, young women, elderly men and elderly women.

2. Each group was studied while the subjects were eating two diets in turn, which differed in their contents of unavailable carbohydrate; the young women were also studied on a third diet which was rich in unavailable carbohydrate.

3. Increasing the intake of unavailable carbohydrate resulted in a greater faecal loss of energy, and in most instances of nitrogen and fat.

4. There was no significant effect of sex or age on the apparent digestibility of protein, fat or available carbohydrate.

5. The results are used to evaluate the use of calorie conversion factors for calculating the metabolizable energy content of mixed diets.

6. These show that for practical purposes the classical Atwater factors can be used to calculate the metabolizable energy of a diet with reasonable accuracy, provided that when available carbohydrate (as monosaccharides) values are used in the calculation a factor of $3.75 \mathrm{kcal} / \mathrm{g}$ $(15.7 \mathrm{~kJ} / \mathrm{g})$ is used.

7. The studies demonstrate that the accuracy of any method for calculating the metabolizable energy of a diet is largely determined by the accuracy with which the method is capable of predicting the gross energy of the diet.
\end{abstract}

The measurement of the metabolizable energy supplied by a diet is not technically difficult, but in practice such measurements are time-consuming, expensive and, most important of all, they place quite severe restrictions on the activities and mode of life of the person eating the diet. In addition, a knowledge of the metabolizable energy supplied by the dietary intake is often required in situations where its direct measurement is impossible or, at best, highly impracticable. In these situations the only alternative is to use a procedure for calculating the metabolizable energy of a diet from its chemical composition.

The various systems of calorie conversion factors provide a method for performing this calculation. All the systems used at present have their origins in work carried out at the end of the last century and the beginning of the present one (Rubner, $188_{5}$; Atwater, 1903).

Atwater and his colleagues carried out a considerable amount of experimental work with human volunteers, which has been admirably reviewed by Merrill \& Watt (I955), but most of the modifications of the 'classical' Atwater factors have been based on 
Atwater's original experimental work (FAO, 1947; Osmond, 1948; Merrill \& Watt, I955; Watt \& Merrill, 1964).

Maynard (1944) drew attention to the misuse of the Atwater calorie conversion factors when they were applied to single foods or mixed diets which differed from the mixed diets for which they were derived (Merrill \& Watt, r955), and since then there has been considerable speculation as to the correct factors to apply to mixed diets eaten at the present time in Great Britain (Hollingsworth, 1955; Widdowson, 1955, 1960). Part of this uncertainty is due to the use of carbohydrate 'by difference' in the Atwater system and to the British preference for 'available carbohydrate' measured directly (McCance \& Widdowson, I960).

The investigation described in the present paper was designed as an experimental evaluation of the calorie conversion factors applicable to diets similar to those eaten in Britain at the present time. It was decided to study a number of individuals on two diets, which differed considerably in content of unavailable carbohydrate. The reason for this decision was that the major point of difference between the procedures used in calculating metabolizable energy in Great Britain and the United States was in respect of carbohydrate (Widdowson, I960).

\section{MATERIALS AND METHODS}

\section{The experimental design}

The study was planned as an 'observational' one on four groups of subjects eating two types of diet. Diet I contained no fruit or vegetables (except potato); diet 2 contained fruit, vegetables and wholemeal bread. The first diet was thus low in the plant polysaccharides which formed the 'unavailable carbohydrates' of McCance \& Lawrence (1929). A third diet, which contained larger amounts of fruit and vegetables (diet 3), was also eaten by the group of young women.

The subjects lived in a university hall of residence or a YWCA hostel in Glasgow during the course of the investigation. Each group was studied for a period of about I month. In the first part of the study the diet eaten was the one low in unavailable carbohydrates; there was a preliminary period of 2-3 $d$ when the subjects ate the diet but no excreta were collected. This was followed by a $7 \mathrm{~d}$ balance period. The faeces were marked with carmine and, as soon as the faecal collections were completed for most of the subjects in the group, the diet was changed to the one containing more unavailable carbohydrate, and there was a $5 \mathrm{~d}$ preliminary period followed by a $7 \mathrm{~d}$ balance period. The third diet (rich in unavailable carbohydrate) was studied on a separate occasion with a $7 \mathrm{~d}$ preliminary period followed by a $7 \mathrm{~d}$ balance period.

\section{The subjects}

The subjects were all volunteers. They were all apparently healthy Europeans who had not lived abroad for any length of time. Each subject was interviewed and a medical history was taken at the start of each study. Four groups were studied and their mean ages, heights and weights are given in Table I. A complete copy of all the original results has been deposited in the Library of the Dunn Nutritional Laboratory, 

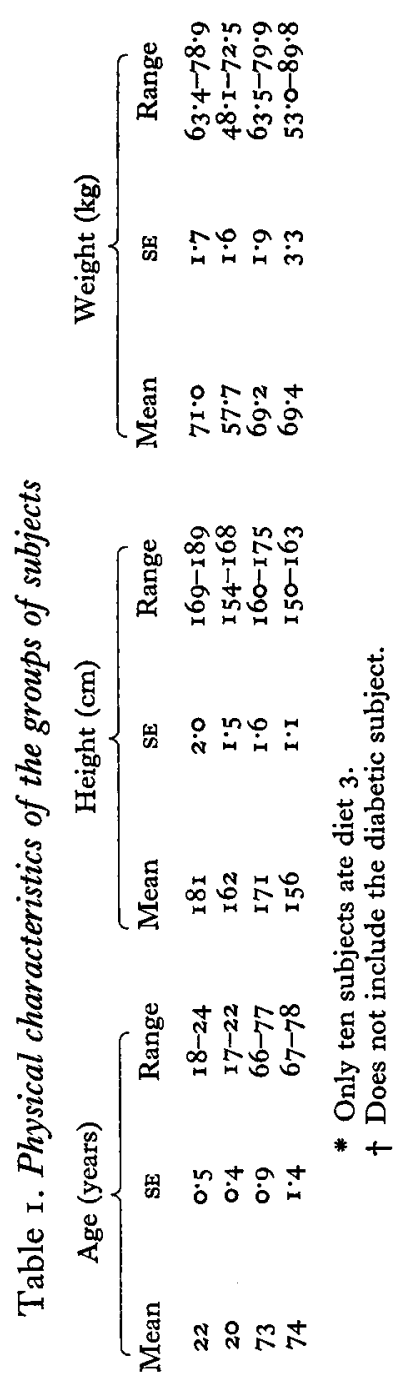

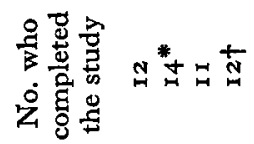

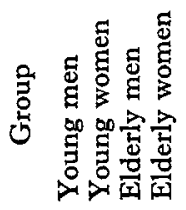


Cambridge, and is available on request. Three elderly men did not complete the study; one elderly woman was subsequently found to be a diabetic and her results have been excluded from the means.

\section{Measurement of dietary intake}

All the dietary procedures were designed so that the amounts of food eaten were accurately known for each subject and so that a truly representative sample of the diet was taken for subsequent analysis. All the items of food making up the diet were specially selected for uniformity; the visible fat was trimmed from meats and bacon to avoid any variation from portion to portion, and frying was not used as a method of cooking. The individual portions for each meal were weighed out and two or three taken at random for analysis. All subjects within each group received, and consumed, identical amounts of the meals prepared in this way (providing about $1600-2000 \mathrm{kcal} / \mathrm{d}$, $6 \cdot 7-8 \cdot 4 \mathrm{MJ})$.

When the diets containing increased amounts of unavailable carbohydrate were being eaten each subject had a ration of wholemeal bread to consume. The weights of the replicates, as collected, after drying and on subsequent analysis indicated a level of precision of the order of $\pm \mathrm{I} \%$. In addition, each subject had his or her own container of white bread, butter, seedless jam, jelly marmalade, sugar and salt; these were weighed daily and the subjects could consume as much as they wished of these 'extra foods'. Beer or soft drinks were available in measured amounts on request to both male groups; the women were restricted to a choice of soft drinks. All the subsequent comments and results refer to the total dietary intake of the subjects.

All meals were closely supervised and two or more of the observers lived with the subjects in the hostel or hall of residence.

\section{Collection of urine and faeces}

Urine was collected under toluene. The collections were made over $24 \mathrm{~h}$ periods, beginning on the morning following the start of the balance period. Faeces were marked for the balance periods by giving carmine in gelatin capsules with a methyl cellulose biscuit at midnight on the evening before the balance period started or ended. The faeces were collected in plastic pots which were transferred to the laboratory in the morning, after lunch and in the evening. The stools were then examined, weighed and transferred with an equal weight of water to a glass jar. The combined faeces were stored in the refrigerator with toluene added as a bacteriostatic agent.

\section{Analytical methods}

Preparation for analysis. The replicates of the diet eaten by all subjects were homogenized each day and the major portion was dried, first on a boiling water bath, then under reduced pressure to constant weight. A portion of the homogenate was saturated with benzoic acid and stored at $0-4^{\circ}$ for determination of carbohydrates.

The combined faecal collection for the balance period was homogenized and the major part of the homogenate dried in a way similar to that used for the diet; a portion was acidified with sulphuric acid for total nitrogen determination. 
Bomb calorimetry. The heats of combustion of samples of diets, 'extra foods', urine and faeces were measured using an adiabatic bomb calorimeter (Gallenkamp Limited). The jam, marmalade, beverages and urines were freeze-dried before bomb calorimetry and the urinary solids after this treatment were handled in a 'glove-box' flushed with dry nitrogen. This was essential because the urinary solids were extremely hygroscopic.

Total solids. These were measured by drying to constant weight at $98-100^{\circ}$ in an air-oven for all samples except the soft drinks, beers and urines. For soft drinks, solids were measured by benzene distillation, and beers and urines were evaporated to dryness on a water-bath and then dried under reduced pressure over $\mathrm{P}_{2} \mathrm{O}_{5}$.

$A s h$. A portion of the sample was dried in a silica crucible, heated over a bunsen burner until fuming ceased and then in an electric muffle furnace at $475^{\circ}$ until a white or grey ash was produced.

Total nitrogen. This was measured by the micro-Kjeldahl method using the catalyst mixture and digestion conditions of Chibnall, Rees \& Williams (1943).

Fat. Fat was measured by a modification of the official acid-hydrolysis method of the Association of Official Agricultural Chemists (1950). The lipid extract obtained in this way was saponified with ethanolic $\mathrm{NaOH}$; the solution was acidified and the fatty acids were extracted with petroleum spirit and weighed after removal of the solvent at low temperature.

Carbohydrates. The various species were measured directly following the principles described by Southgate $(1969 a, b)$.

Alcohol. This was measured in the beer by the Inland Revenue distillation method.

Urinary constituents. Urea was measured by the method of Lee \&Widdowson(1937); creatinine by Folin's method as described by Hawk, Oser \& Summerson (1954); uric acid by King's ( 1946 ) method and ammonia by distillation after adjustment of the $\mathrm{pH}$ to phenol-red end-point (approx. 6.8).

\section{RESULTS}

The values for the individual subjects can be found in the original results (see p. ${ }^{1}$ 8). In all cases the values for intake and excretion are expressed per head per day of the $7 \mathrm{~d}$ balance period.

The term 'balance' is used for the difference between intake and total excretion and is by convention positive when intake exceeds excretion.

The term 'apparent digestibility' is defined as the difference between intake and faecal excretion expressed as a percentage of the intake.

\section{Intake and excretion of energy}

The mean values are given in Table 2. The intake varied considerably within each group. As would be expected, the young took more than the elderly and the men more than the women. The differences between the intakes on the different diets by any one group were, however, quite small and there was a tendency for the higher intake to occur on the diet containing more unavailable carbohydrate.

Faecal losses of energy within a group on any one diet were quite variable. The 
losses of energy in the faeces were significantly higher on the diets containing more unavailable carbohydrate.

The urinary losses of energy were similar for all groups and all diets.

\section{Intake and excretion of nitrogen}

The mean values for the intake and excretion of nitrogen are given in Table 3 . Within each group the intake was reasonably constant for any diet, and the individual variation observed was a consequence of the different amounts of bread eaten by individuals. The differences between the absolute intakes of the groups were proportional to the differences in energy intakes, and the percentage of the gross energy intake supplied by protein was similar for all groups.

Faecal excretion of nitrogen was very variable within each group, and the highest faecal excretion for any diet was sometimes nearly three times the lowest.

The mean excretion of nitrogen was always higher for diet 2 than for diet $I$, and the differences were significant at the $5 \%$ level. For the young women the excretion on diet 3 was significantly higher than that on diet $2(P<0.001)$.

Urinary excretion of nitrogen showed less individual variation and accounted for some $75-80 \%$ of the intake for most subjects.

The mean values for the nitrogen balance show that, on average, all subjects were in positive balance, although the values obtained were all within the ranges of dermal losses reported by other workers (Consolazio, Nelson, Matoush, Harding \& Conham, 1963; Sirbu, Margen \& Calloway, 1967). The elderly subjects were in greater apparent positive balance than the young ones.

\section{Intake and excretion of fat}

The mean values for the intake and faecal excretion of fat are given in Table 4. Intake varied within each group, reflecting the different individuals' consumption of butter. The differences in the amounts eaten by the different groups were, in general, proportional to the total energy intake, and fat provided between 30 and $37 \%$ of the gross energy intake for most individuals.

Table 4. Intake and excretion of $f a t(g / d)$

\begin{tabular}{|c|c|c|c|c|c|c|c|}
\hline \multirow[b]{2}{*}{ Group } & \multirow[b]{2}{*}{ Diet } & \multicolumn{3}{|c|}{ Intake } & \multicolumn{3}{|c|}{ Faecal excretion } \\
\hline & & Mean & SE & Range & Mean & SE & Range \\
\hline Young men & $\begin{array}{l}\mathbf{I} \\
2\end{array}$ & $\begin{array}{l}115 \cdot 8 \\
125 \cdot 1\end{array}$ & $\begin{array}{l}2 \cdot 86 \\
5 \cdot 34\end{array}$ & $\begin{array}{r}95^{\circ} 4-135 \cdot 3 \\
105 \cdot 8-158.0\end{array}$ & $\begin{array}{l}4 \cdot 13 \\
6 \cdot 40\end{array}$ & $\begin{array}{l}0.32 \\
0.31\end{array}$ & $\begin{array}{l}2 \cdot 43-5 \cdot 57 \\
5 \cdot 11-8 \cdot 90\end{array}$ \\
\hline Young women & $\begin{array}{l}1 \\
2 \\
3\end{array}$ & $\begin{array}{l}92 \cdot 0 \\
96 \cdot 1 \\
89 \cdot 2\end{array}$ & $\begin{array}{l}3 \cdot 13 \\
2 \cdot 72 \\
1 \cdot 30\end{array}$ & $\begin{array}{l}73 \cdot 7-\text { I I } 4 \cdot 2 \\
80 \cdot 5-121 \cdot 1 \\
84 \cdot 7-99 \cdot 6\end{array}$ & $\begin{array}{l}3 \cdot 01 \\
3 \cdot 69 \\
6 \cdot 24\end{array}$ & $\begin{array}{l}0.21 \\
0.18 \\
0.31\end{array}$ & $\begin{array}{l}I \cdot 93-4 \cdot 51 \\
2 \cdot 39-4 \cdot 79 \\
4 \cdot 94-7 \cdot 61\end{array}$ \\
\hline Elderly men & $\begin{array}{l}\text { I } \\
2\end{array}$ & $\begin{array}{r}105 \cdot 9 \\
98 \cdot 9\end{array}$ & $\begin{array}{l}5 \cdot 14 \\
4 \cdot 06\end{array}$ & $\begin{array}{l}84^{\circ} 5^{-1} 34^{*} \mathrm{I} \\
79^{\circ} 7^{-123} \cdot 8\end{array}$ & $\begin{array}{l}5 \cdot 07 \\
5 \cdot 4 x\end{array}$ & $\begin{array}{l}0.35 \\
0.36\end{array}$ & $\begin{array}{l}3.30-7 \cdot 01 \\
3.60-7.37\end{array}$ \\
\hline Elderly women & $\begin{array}{l}1 \\
2\end{array}$ & $\begin{array}{l}82 \cdot 4 \\
92 \cdot 6\end{array}$ & $\begin{array}{l}2 \cdot 88 \\
3 \cdot 26\end{array}$ & $\begin{array}{l}66 \cdot 4-96 \cdot 3 \\
79 \cdot 7^{-1} 12 \cdot 5\end{array}$ & $\begin{array}{l}4 * 49 \\
479\end{array}$ & $\begin{array}{l}0.30 \\
0.02\end{array}$ & $\begin{array}{l}2 \cdot 27-6 \cdot 24 \\
2 \cdot 57-6 \cdot 10\end{array}$ \\
\hline
\end{tabular}

Faecal excretion of fat varied greatly between individuals and was not correlated with intake. In all groups the mean faecal excretion was higher on diet 2 than on diet $\mathrm{I}$, 
but the difference was only significant for the young men $(P<0.001)$ and the young women $(P<0.01)$; the excretion of fat on diet 3 by the young women was significantly higher $(P<0.00 \mathrm{r})$ than on diet 2.

Table 5. Intake of sugars and starches ( $g$ monosaccharide/d)

\begin{tabular}{|c|c|c|c|c|c|c|c|}
\hline \multirow[b]{2}{*}{ Group } & \multirow[b]{2}{*}{ Diet } & \multicolumn{3}{|c|}{ Sugars } & \multicolumn{3}{|c|}{ Starches } \\
\hline & & Mean & SE & Range & Mean & $\mathrm{SE}$ & Range \\
\hline Young men & $\begin{array}{l}\text { I } \\
2\end{array}$ & $\begin{array}{l}210 \\
226\end{array}$ & $\begin{array}{l}10.6 \\
12.6\end{array}$ & $\begin{array}{l}123-273 \\
137-309\end{array}$ & $\begin{array}{l}\text { I84 } \\
\text { I } 75\end{array}$ & $\begin{array}{l}6 \cdot 1 \\
6 \cdot 8\end{array}$ & $\begin{array}{l}\text { I } 43-226 \\
\text { I } 54-240\end{array}$ \\
\hline Young women & $\begin{array}{l}\text { I } \\
2 \\
3\end{array}$ & $\begin{array}{l}135 \\
167 \\
219\end{array}$ & $\begin{array}{l}5 \cdot 6 \\
5 \cdot 2 \\
5 \cdot 7\end{array}$ & $\begin{array}{r}99-174 \\
126-202 \\
196-247\end{array}$ & $\begin{array}{r}127 \\
95 \\
100\end{array}$ & $\begin{array}{l}4 \cdot 3 \\
1 \cdot 5 \\
0 \cdot 3\end{array}$ & $\begin{array}{r}87-154 \\
90-106 \\
100-103\end{array}$ \\
\hline Elderly men & $\begin{array}{l}\text { I } \\
2\end{array}$ & $\begin{array}{l}180 \\
204\end{array}$ & $\begin{array}{r}\text { II.0 } \\
9.0\end{array}$ & $\begin{array}{l}121-266 \\
157-259\end{array}$ & $\begin{array}{l}205 \\
148\end{array}$ & $\begin{array}{l}8 \cdot 5 \\
6 \cdot 9\end{array}$ & $\begin{array}{l}\text { I } 57-245 \\
\text { I } 24-189\end{array}$ \\
\hline Elderly women & $\begin{array}{l}\text { I } \\
2\end{array}$ & $\begin{array}{l}130 \\
171\end{array}$ & $\begin{array}{l}7 \cdot 4 \\
7 \cdot 9\end{array}$ & $\begin{array}{r}97-189 \\
138-213\end{array}$ & $\begin{array}{l}128 \\
\times 20\end{array}$ & $\begin{array}{l}5 \cdot 7 \\
2 \cdot 6\end{array}$ & $\begin{array}{r}94-164 \\
107-132\end{array}$ \\
\hline
\end{tabular}

\section{Intake and excretion of carbohydrates}

Available carbohydrates. The mean values for the intake of available carbohydrates given in terms of sugars and starches expressed as monosaccharides are given in Table 5. There was considerable individual variation in the intake of sugars in particular, which was a consequence of individual variation in the consumption of granulated sugar. The variation in the intake of starch was a reflection of the amounts of 'extra' bread consumed.

No appreciable amounts of free sugars or starches could be detected in the faeces of any subject, and accordingly no values for the excretion of these carbohydrates are given.

Unavailable carbohydrates. The diets provided negligible amounts of pectic substances and the unavailable carbohydrates in the diet were made up almost completely of cellulose and a mixture of many different heteropolysaccharides in which the pentoses, xylose and arabinose were by far the most important components; these have been grouped in Table 6 under the heading 'pentosans'. The cellulose values also include the traces of lignin which these diets contained.

There was less individual variation in the intake of both these groups of substances because the 'extra' foods (white bread, butter, jam, marmalade and granulated sugar) were relatively minor sources of these substances.

Table 6 shows that, in accordance with the experimental design, diet 2 provided much more unavailable carbohydrate than diet $\mathrm{I}$, and diet 3 even more.

Pentosans supplied approx. $\mathrm{I} \%$ of the gross energy intake on diet $\mathrm{I}$ and about $2-3 \%$ on diet 2 . Cellulose provided between 0.2 and $0.4 \%$ of the gross energy intake on diet $\mathrm{r}$, about $\mathrm{r} \%$ on diet 2 and $\mathrm{r} \cdot 5 \%$ on diet 3 .

The faecal excretion of both types of carbohydrate was variable, and in all instances the excretion was greater on the diets containing more of these carbohydrates. The faecal excretion of pentosan was, however, eight to ten times higher on diet 2 than on diet I although the intake was only two or three times as high. 


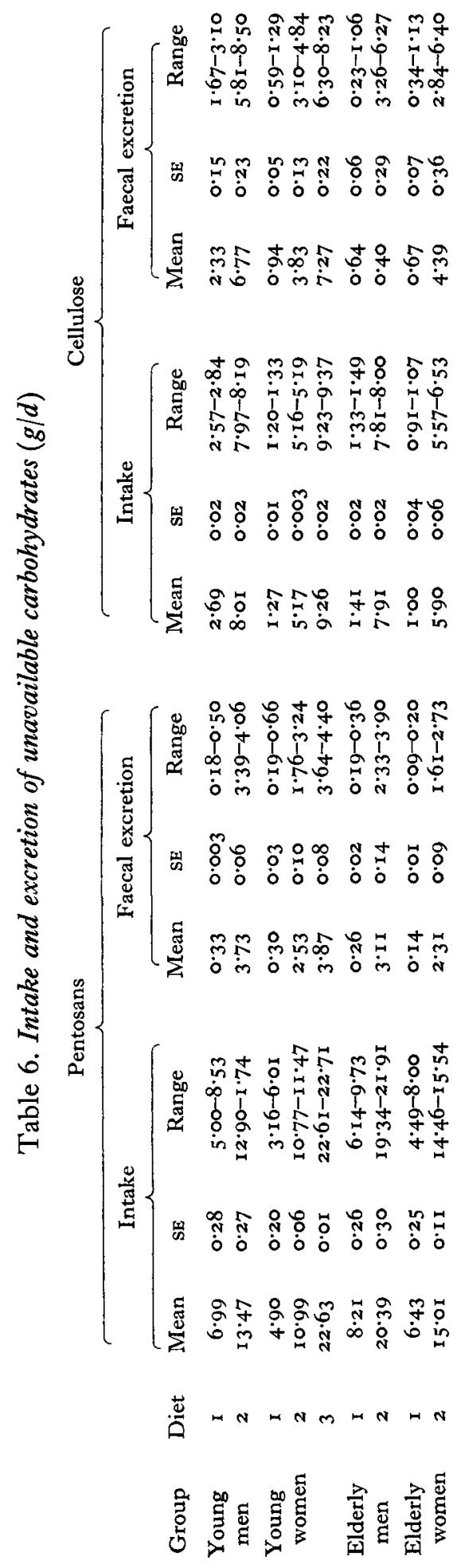


The excretion of cellulose was the most variable of any constituent studied, but was approximately proportional to intake. One or two subjects in most groups showed anomalous values for excretion, for the amount excreted was slightly greater than the intake.

\section{Apparent digestibility of the dietary constituents}

The mean values for the apparent digestibility of the gross energy, protein (total nitrogen $\times 6 \cdot 25$ ), fat, pentosans and cellulose are given in Table 7 . No values are given for 'available carbohydrates' because these were apparently completely digested.

Energy. The individual variation within the groups was very small. The differences between the apparent digestibility of energy for the two diets eaten by each group were highly significant (for all $P<0 \cdot 00 \mathrm{r}$ ). There was no significant difference between the groups for any one type of diet.

Protein. The individual variation within the groups was greater than for energy and the mean values for the apparent digestibility of protein in diet 2 were lower than for diet $\mathrm{I}$; this difference was significant for all groups; for the young women the difference between diet 3 and diet 2 was highly significant (for diet 1 compared to diet 2 in young men and women, $P<0.025$; in elderly men, $P<0.05$; in elderly women, $P<0.001$; in young women for diet 2 compared to diet $3, P<0.001$ ).

Fat. Individual variation was less than observed for protein but greater than that observed for energy. For the young men and young women there was a significant difference between the apparent digestibility of fat on the different diets (young men, $P<0.005$; young women for diet 2 compared to diet $3, P<0.00$ ).

Pentosans. In all instances the pentosans were apparently digested to a greater extent on diet $\mathrm{I}$. The difference was highly significant $(P<0.00 \mathrm{I})$ but was almost certainly due to qualitative differences between the pentosans in the different diets.

Cellulose. There was a great amount of variation between individuals. The difference between the types of diet was only significant for the elderly women $(P<0.05)$.

\section{Difference between the groups}

There was a significant difference between the apparent digestibility of protein for the groups of young men and women (diet $\mathrm{r}, P<0.05$; diet $2, P<0.00 \mathrm{I}$ ).

The differences in the digestibility of the fat for the young and elderly groups were significant for diet I (men, $P<0.025$; women, $P<0.001$ ); for diet 2 , however, only the female groups showed a significant difference $(P<0.001)$.

The differences between the means for the apparent digestibility of cellulose were only significant $(P<0.00 \mathrm{I})$ for the male groups.

\section{Partition of the urinary nitrogen}

The partition of the urinary nitrogen amongst the various constituents and the calorie:nitrogen ratio as determined by bomb calorimetry are given in Table 8 . The calorie: nitrogen ratio varied between $7 \cdot \mathrm{I}$ and $\mathrm{Ir} \cdot 6 \mathrm{kcal} / \mathrm{g} \mathrm{N}$, but the mean values for all groups and diets were similar and the highest coefficient of variation for any group was $12.9 \%$ (elderly women, diet I). One of the elderly women who began the study 
Vol. 24

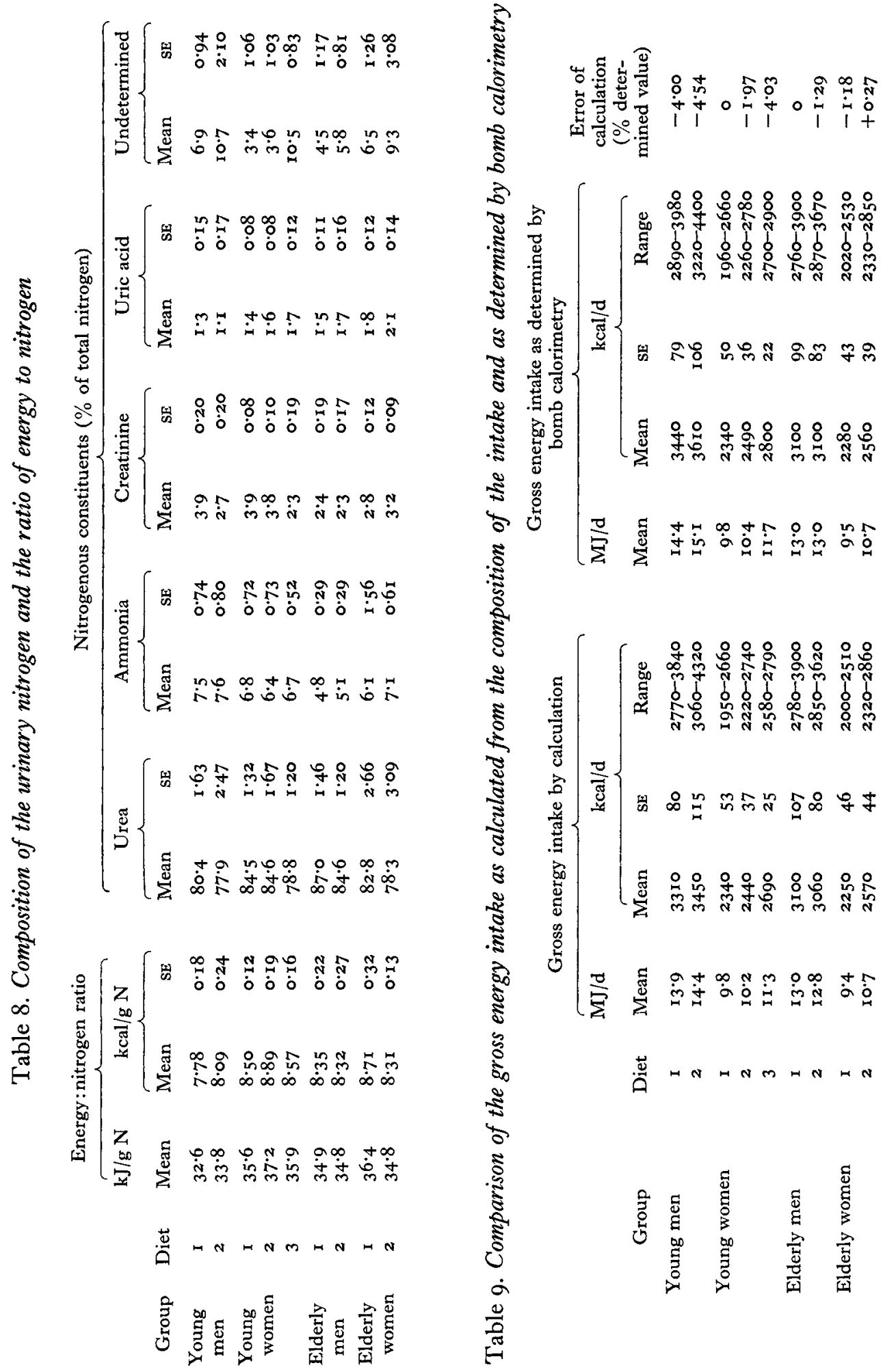


was found to be a diabetic, and whose results are not included in the means, had a calorie: $\mathrm{N}$ ratio of over $60 \mathrm{kcal} / \mathrm{g} \mathrm{N}$ in her urine.

The partition of the urinary nitrogen showed no significant differences between groups or diets. The values obtained were very similar to those reported in the literature (Folin, I905; Graham \& Poulton, I912; Smith, 1926).

\section{DISCUSSION}

In making a re-evaluation of any method for calculating the metabolizable energy of a diet it is essential to consider the term 'metabolizable energy'. This is defined by Blaxter \& Graham (r955) as the difference between the gross energy intake (i.e. the heat of combustion of the diet) and the heats of combustion of the urinary and faecal excretions and, strictly, of any other losses of energy in secretions and, in the ruminant especially, intestinal gases. In our study, as in most human metabolic studies, the losses in secretions or gases have been ignored as they are probably small and certainly very difficult to measure. Any method of calculation can therefore be evaluated as a method for predicting, from the chemical composition of a diet, first, its gross energy content, second the urinary losses of energy and third the faecal losses of energy or, more usually, the digestible energy of the diet.

\section{Prediction of gross energy intake}

This represents the most important part of the overall calculations as the losses of energy in the urine and faeces are small relative to the gross energy intake. The gross energy intake is equal to the sum of the products of the heats of combustion of each constituent multiplied by the amount of each constituent eaten. Thus if the amounts eaten are known the only requirement is a knowledge of the heats of combustion of the substances found in foods. Atwater determined the heats of combustion of many isolated constituents of foods (Merrill \& Watt, I955) and computed average heats of combustion for the protein, fat and carbohydrate in mixed diets. Atwater \& Bryant (I900) showed that these average values predicted the heat of combustion of foods with considerable accuracy. From the data compiled by Merrill \& Watt (1955) it is possible to compute the expected heat of combustion of the protein in the diets in the present study, and this appears to be the same as that used by Atwater, namely $5.65 \mathrm{kcal} / \mathrm{g}$ protein $(\mathrm{N} \times 6.25)(23.6 \mathrm{~kJ})$. The fat isolated in good yield $(>98 \%)$ from the diets used in the present study had a determined heat of combustion of $9.35 \mathrm{kcal} / \mathrm{g}\left(39^{\cdot} \mathrm{I} \mathrm{kJ}\right)$. For carbohydrates the heats of combustion are well documented, and we have used $3.75 \mathrm{kcal} / \mathrm{g}$ ( $15.7 \mathrm{~kJ}$ ) for monosaccharides and $4.2 \mathrm{kcal} / \mathrm{g}$ ( $17.6 \mathrm{~kJ}$ ) for polysaccharides; the heat of combustion of alcohol has been taken as $7 \cdot 1 \mathrm{kcal} / \mathrm{g}$ $(29 \cdot 7 \mathrm{~kJ})$.

Using these heats of combustion and the amounts of protein, fat, carbohydrates and alcohol consumed by the subjects in the present study we obtained the gross energy intakes shown in Table 9, where they are compared with the values determined by bomb calorimetry. In all instances the ranges of the determined and calculated values are similar and in all but three instances the determined and calculated values 
are in good agreement. The mean error of calculation, expressed as a percentage of the determined values, is $-\mathrm{r} \cdot 87$, so that for practical purposes the heats of combustion adopted seem to be reliable. The table does, however, show that in some instances the error of calculation is about $5 \%$, and this suggests that for some reason the gross energy intake calculated in this way is not as accurate as one would wish. Macy (1942) observed a similar discrepancy between calculated and determined gross energy contents of diets.

\section{Prediction of the energy loss in urine}

Most of the organic matter in urine is nitrogenous and arises from the inability of the body to oxidize nitrogenous compounds completely. Both Rubner and Atwater measured the ratio of energy: nitrogen in urine and, despite the considerable variation, decided that the best way to allow for the energy loss in urine was to make a deduction from the heat of combustion of protein. The deduction of $1 \cdot 25 \mathrm{kcal} / \mathrm{g}(5 \cdot 23 \mathrm{~kJ})$ of protein used by Atwater is based on a mean value of $7.9 \mathrm{kcal} / \mathrm{g} \mathrm{N}(33 . \mathrm{IJJ})$ which in turn was based on measurements on forty-six specimens of urine (see Merrill \& Watt, 1955). When this deduction was first proposed it was not realized that it applied per gram of protein absorbed and this has led to some confusion (Merrill \& Watt, 1955; Widdowson, I955).

In the present study a similar wide variation was observed in the energy: nitrogen ratio, as can be seen in Table 8 . The variation in the ratio may be due to variations in the proportions of the various nitrogenous constituents and in the amounts of nonnitrogenous organic matter in the urine. Calculation of the expected energy: nitrogen ratio from the nitrogenous constituents gave values which were always lower than the determined values and there was no correlation between calculated and determined ratios. The calculation of the ratio is a little uncertain because of the undetermined nitrogen for which we used the calorific value proposed by Levy, Bernstein \& Grossman (1958), i.e. $26.98 \mathrm{kcal} / \mathrm{g} \mathrm{N}$.

Urinary energy was correlated with both total nitrogen (correlation coefficient $r=+0.789)$ and urinary organic matter $(r=+0.757)$. It is difficult to devise a procedure for predicting urinary organic matter from the composition of the diet, whereas for a subject in nitrogen equilibrium (as would be the case for most adults) urinary nitrogen is approximately equal to the digestible nitrogen.

Examination of the results of the present study shows that, while for individual subjects the use of a mean energy: nitrogen value of $7.9 \mathrm{kcal} / \mathrm{g} \mathrm{N}$ does not predict the urinary energy with any great accuracy, for practical purposes the differences between the urinary energy loss calculated from this mean ratio and the observed urinary energy loss were small and represented less than $0.5 \%$ of the gross energy intake.

\section{Prediction of the energy loss in faeces and digestible energy}

Atwater (I900) was careful to recognize the fact that faeces were not wholly undigested food residues and preferred the term 'availability' to 'apparent digestibility'. He derived 'coefficients of availability' (which were defined as intake minus faecal excretion divided by intake) for the protein, fat and carbohydrate in mixed diets from the results of his experimental work and found that when these were applied to the 


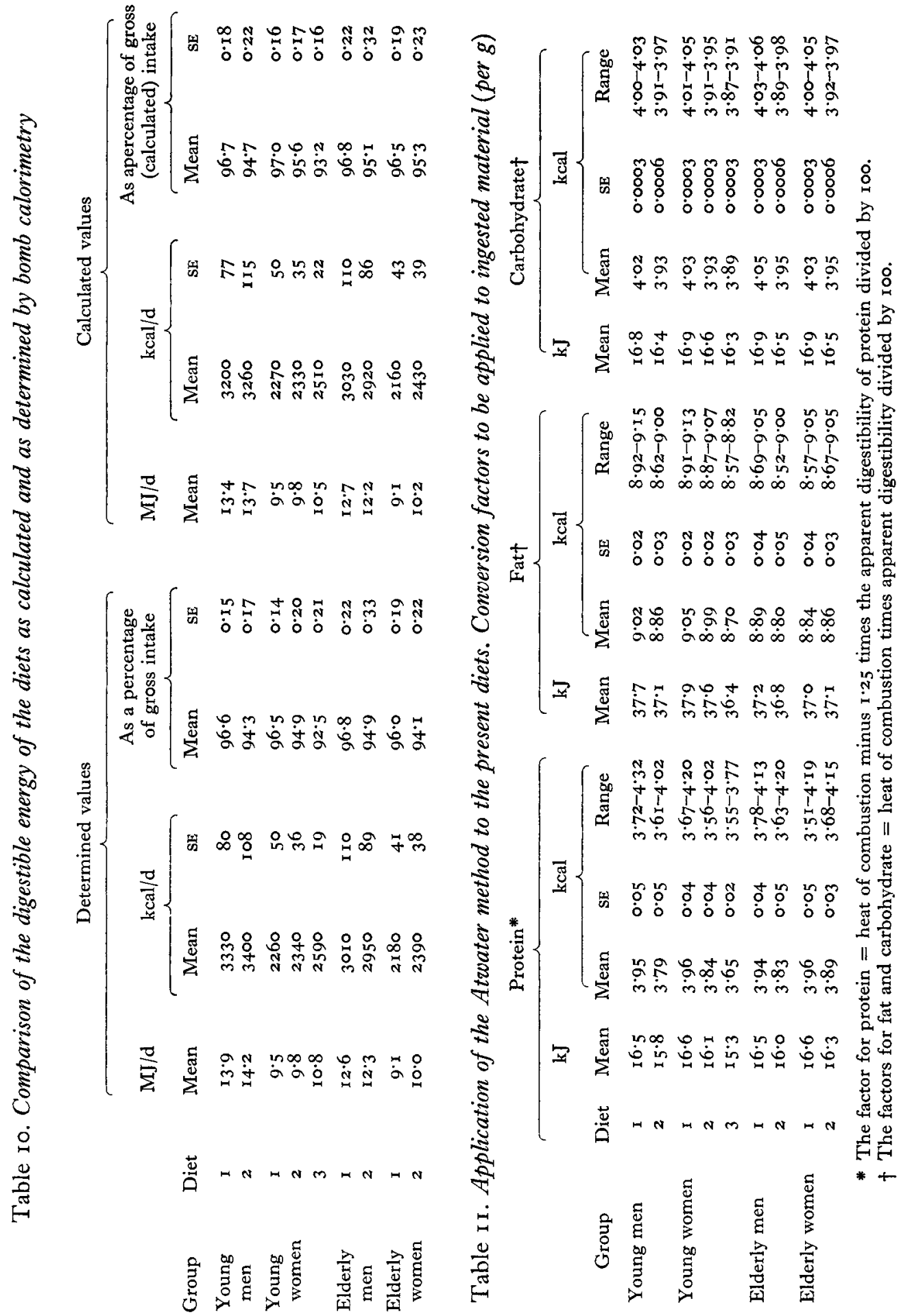


heats of combustion and amounts eaten, they predicted the 'digestible energy' or 'available energy' of the diet with great accuracy.

The application of this procedure to the present findings (Table ro) confirms that there is good agreement between the calculated 'digestible energy' of the diets (i.e. the gross intake minus faecal excretion) and the determined values. The agreement is excellent when the calculated gross energy agreed well with the determined values, and is good for all groups and diets when expressed as a percentage of the gross intake. This emphasizes the point that the prediction of the gross energy intake is the most important stage in the calculation of the digestible energy, and by inference, the metabolizable energy content of a diet.

\section{The effect of unavailable carbohydrate intake}

An increase in the intake of unavailable carbohydrate increases the weight of faecal organic matter and energy. In the present study the apparent digestibility of the energy was significantly lower for the diet containing more unavailable carbohydrate. The digestible energy expressed as a percentage of the gross energy intake was correlated with the percentage of the gross energy intake supplied by unavailable carbohydrate (pentosans+cellulose). The correlation coefficient was -0.965 and the regression

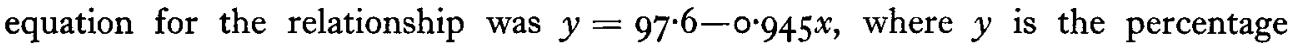
digestible energy and $x$ is energy from unavailable carbohydrate expressed as a percentage of the gross energy. There would therefore appear to be considerable justification of McCance \& Widdowson's (1960) exclusion of the unavailable carbohydrates from any calculation of metabolizable energy.

The increase in faecal excretion of energy was not, however, completely accounted for by the increased excretion of unavailable carbohydrate because there was an accompanying increased excretion of nitrogen and fat, although these increases were not always statistically significant. There were qualitative differences between diets I and 2 in that the proportion of protein in the diet derived from vegetables and wholemeal bread was very different. Atwater (see Merrill \& Watt, 1955) reported differences in the apparent digestibility of the protein in wholemeal wheat compared with 70-74\% extraction wheat. McCance \& Widdowson (1947) showed that this difference is most probably due to the differences in the unavailable carbohydrate contents of these two foods. Unavailable carbohydrate may, by increasing the bulk of the intestinal contents, accelerate the rate of passage through the intestine as found by McCance, Prior \& Widdowson (1953). The rate of passage of the faecal marker dye was very variable in the present study, and it is not possible to make any deductions from our figures. It would be expected that an increased rate of passage would reduce the amounts of substances absorbed from the intestine. It is also probable that nutrients lying within any intact plant cells would be less accessible to the digestive enzymes and might therefore be less well digested and absorbed.

\section{Apparent digestibility of the unavailable carbohydrates}

The present results show that some of the pentosans and cellulose were apparently digested during their passage through the intestinal tract. There was great individual 


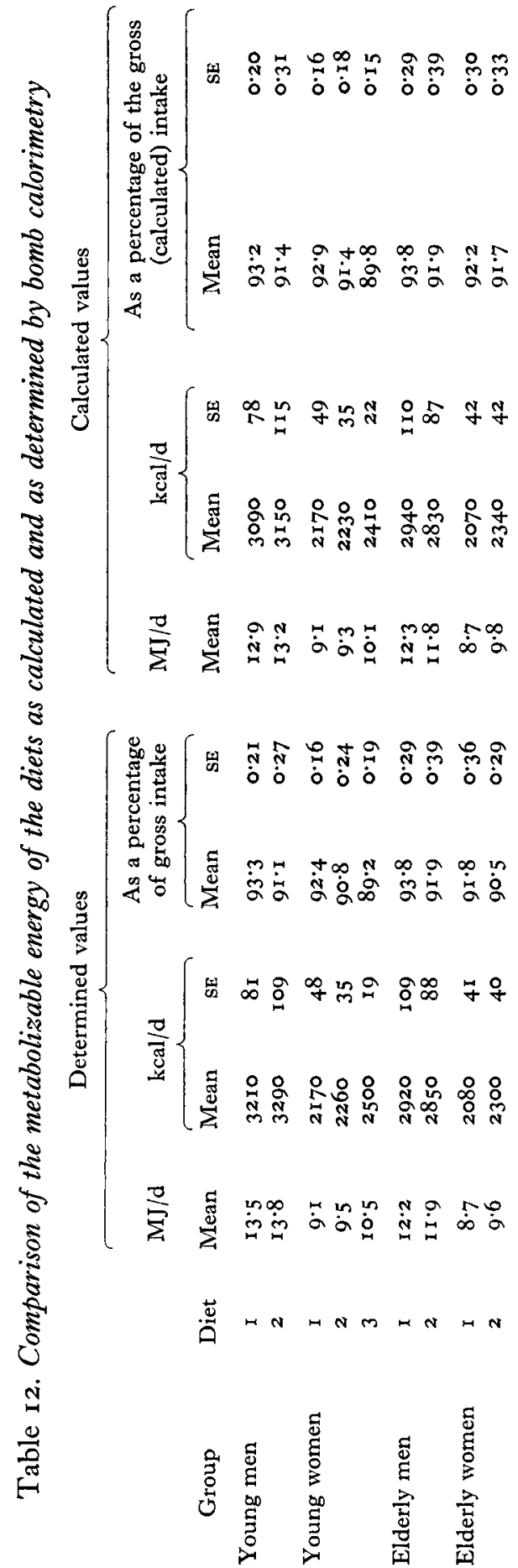


variation in the proportion that was apparently digested, as was found by Macy, Hummel \& Shepherd (I943) and Kowalski \& Piekarska (1957). These differences are probably due to variations in the composition of the intestinal microflora and there is no recent evidence to dispute the statement of McCance \& Lawrence (I929) that 'starch is the only polysaccharide hydrolysed by the mammalian digestive system'. They and others since (Mangold, 1934; Southgate, I964) came to the conclusion that any breakdown of other polysaccharides was a result of the activities of the intestinal micro-organisms.

It is probable that the complete absence of sugars and starches from all the faeces in this study reflects a combination of the efficiency of absorption from the intestine and the efficiency of utilization by the intestinal microflora (Southgate, 1964).

\section{Effect of age of subject}

The elderly subjects did not show any real evidence of a reduced capacity to 'digest' the types of diet provided in these studies, in fact more cellulose disappeared during the passage through the intestinal tract in the elderly subjects than in the young. This may be a consequence of a slower rate of passage which provided a longer time for the intestinal micro-organisms to degrade the cellulose.

\section{Derivation of calorie conversion factors from the present results}

Following the procedure used by Atwater (Merrill \& Watt, 1955), it is possible to derive a series of calorie conversion factors appropriate to the diets studied. These are given in Table II. The factors for carbohydrates are for 'total carbohydrate' by analysis (Southgate, $1969 a, b$ ), which in the present study was very nearly the same as carbohydrate 'by difference'.

The mean values for protein, fat and carbohydrate are very near the 'classical' 4, 9, 4 factors of Atwater, and only where the diet contained a large amount of unavailable carbohydrates were the factors significantly different for protein and fat, that is for the young women on diet 3 . The factor for carbohydrate falls as the proportion of unavailable carbohydrate increases; if, however, available carbohydrate is substituted for total carbohydrate the factor is unchanged for all diets at $3.75 \mathrm{kcal} / \mathrm{g}$, expressed as monosaccharides and, for practical purposes, the energy contributed by the apparently digested unavailable carbohydrates can be ignored. Table 12 shows the comparison of the metabolizable energy contents of the diets calculated in this way and the observed values based on bomb calorimetry. The agreement is good on an absolute basis and particularly so when expressed as a percentage of the calculated gross energy.

The results show that the accuracy with which calorie conversion factors predict the metabolizable energy content of a diet is largely determined by the accuracy with which that part of the factors concerned with gross energy predicts the gross energy content of the diet. The accuracy with which the system predicts the faecal and urinary losses of energy is of little importance, as these represent only a small part of the equation defining metabolizable energy.

For practical purposes, the Atwater factors for protein and fat may be applied to contemporary British diets with little error. For available carbohydrate, expressed as 
monosaccharides, the heat of combustion for monosaccharide sugars $(3.75 \mathrm{kcal} / \mathrm{g})$ should be used. If the diet contains large amounts of unavailable carbohydrate, the Atwater protein and fat factors may slightly overestimate the energy derived from these constituents.

There does, however, on the basis of the present evidence, seem to be insufficient justification for the use of specific calorie conversion factors for different foodstuffs (Merrill \& Watt, I955) which incorporate specific coefficients of availability; the accuracy of calculations of metabolizable energy would probably be best improved by devoting more attention to the gross energy content of different foodstuffs rather than by attention to the 'digestibility' of the different components of foods.

It would seem most likely that a more accurate prediction of the metabolizable energy in a diet could be made if it were based, albeit more empirically, on actual determinations of the heats of combustion of foods or diets as proposed by Levy et al. (1958) and Miller \& Payne (1959), although the present work shows that the equations for metabolizable energy proposed by both these groups of workers may be slightly over-simplified.

A study such as this requires a team of skilled workers and we would especially like to acknowledge the professional support of Dr J. M. Brockway, Mrs Elaine C. Taylor, Miss Irene M. Barrett and Dr Anna Ferro-Luzzi and the dieticians and technicians whose skill played a vital part in this work. The wardens of McBrayne Hall, University of Glasgow and of the YWCA Hostels in Woodlands and Claremont Terraces helped considerably with the smooth running of these studies. Several firms provided material or special facilities and we would like to acknowledge the help of Beatties Limited of Glasgow, Rank (Millers) Limited, Allinsons Limited and Schweppes. The major part of the chemical work was carried out in the former Department of Experimental Medicine, in Cambridge, and the guidance of Professor R. A. McCance and Dr E. M. Widdowson was invaluable.

\section{REFEREN CES}

Association of Official Agricultural Chemists (1950). Official Methods of Analysis 7th ed., p. 196. Washington, DC: Association of Official Agricultural Chemists.

Atwater, W. O. (1900). Twelfth Ann. Rep. Storrs agric. Exp. Stn p. 69.

Atwater, W. O. (1903). Fifteenth Ann. Rep. Storrs agric. Exp. Stn p. 123.

Atwater, W. O. \& Bryant, A. P. (1900). Twelfth Ann. Rep. Storrs agric. Exp. Stn p. 73.

Blaxter, K. L. \& Graham, N. McC. (1955). Proc. Nutr. Soc. I4, I3 I.

Chibnall, A. C., Rees, M. W. \& Williams, E. F. (1943). Biochem. F. 37, 354.

Consolazio, C. F., Nelson, R. A., Matoush, L. O., Harding, R. S. \& Conham, J. E. (r963). f. Nutr. 79, 399.

FAO (1947). Energy Yielding Components of Food and Computation of Calorie Values. Washington: F.A.O.

Folin, O. (1905). Am. F. Physiol. 13, 66.

Graham, G. \& Poulton, E. P. (1912). Q. Fl Med. 6, 82.

Hawk, P. B., Oser, P. L. \& Summerson, W. H. (1954). Practical Physiological Chemistry 13 th ed. London: J. \& A. Churchill.

Hollingsworth, D. F. (1955). Proc. Nutr. Soc. 14, 54.

King, E. J. (1946). Microanalysis in Medical Biochemistry. London: J. \& A. Churchill.

Kowalski, J. \& Piekarska, J. (1957). Roczn. państ. Zakl. Hig. 8, 557.

Lee, M. H. \& Widdowson, E. M. (1937). Biochem. F. 3I, 2035. 
Levy, L. M., Bernstein, L. M. \& Grossman, M. I. (1958). U.S. Army Med. Res. Nutr. Lab. Rep. no. 226.

McCance, R. A. \& Lawrence, R. D. (1929). Spec. Rep. Ser. med. Res. Coun. no. 135.

McCance, R. A., Prior, K. M. \& Widdowson, E. M. (I953). Br. F. Nutr. 7, 98.

McCance, R. A. \& Widdowson, E. M. (1947). F. Hyg., Camb. 45, 59.

McCance, R. A. \& Widdowson, E. M. (1960). Spec. Rep. Ser. med. Res. Coun. no. 297.

Macy, I. G. (1942). Nutrition and Chemical Growth in Childhood. Springfield, Ill.: C. C. Thomas.

Macy, I. G., Hummel, F. C. \& Shepherd, M. L. (r943). Am. F. Dis. Child. 65, I95.

Mangold, E. (1934). Nutr. Abstr. Rev. 3, 647.

Maynard, L. A. (1944). F. Nutr. 28, 443.

Merrill, A. L. \& Watt, B. K. (1955). Agric. Handbk, U.S. Dep. Agric. no. 74.

Miller, D. S. \& Payne, P. R. (1959). Br. J. Nutr. 13, 50 r.

Osmond, A. (1948). Spec. Rep. Ser. natn. Hlth med. Res. Coun., Canberra no. 2.

Rubner, M. (1885). Z. Biol. 2r, 250.

Sirbu, E. R., Margen, S. \& Calloway, D. H. (1967). Am. Ұ. clin. Nutr. 2o, I 58.

Smith, M. (1926). F. biol. Chem. 68, 15.

Southgate, D. A. T. (1964). The carbohydrates in human faecal material. PhD Thesis, University of London.

Southgate, D. A. T. (1969a). F. Sci. Fd Agric. 20, 326.

Southgate, D. A. T. (1969b). F. Sci. Fd Agric. 20, 33 I.

Watt, B. K. \& Merrill, A. L. (I964). Agric. Handbk, U.S. Dep. Agric. no. 8.

Widdowson, E. M. (1955). Proc. Nutr. Soc. 14, 142.

Widdowson, E. M. (1960). Spec. Rep. Ser. med. Res. Coun. no. 297, p. 153. 